\title{
Azolla Fern in Mwea Irrigation Scheme and Its Potential Nitrogen Contribution in Paddy Rice Production
}

\author{
Wilson A. Oyange ${ }^{1}$, George N. Chemining'wa ${ }^{1}$, James I. Kanya ${ }^{2} \&$ Paul N. Njiruh ${ }^{3}$ \\ ${ }^{1}$ Department of Plant Science and Crop Protection, University of Nairobi, Nairobi, Kenya \\ ${ }^{2}$ School of Biological Sciences, University of Nairobi, Nairobi, Kenya \\ ${ }^{3}$ Department of Agricultural Resource Management, University of Embu, Embu, Kenya \\ Correspondence: Wilson A. Oyange, Department of Plant Science and Crop Protection, University of Nairobi, \\ P.O. Box 29053-00625, Nairobi, Kenya. Tel: 254-711-748-464. E-mail: woyange@yahoo.com
}

Received: September 9, 2019

Accepted: October 19, 2019 Online Published: November 15, 2019

doi:10.5539/jas.v11n18p30

URL: https://doi.org/10.5539/jas.v11n18p30

\begin{abstract}
Azolla fern is invasive in Mwea Irrigation Scheme in Kenya and its management in paddy rice fields is a challenge to farmers. A survey was undertaken to establish farmers' knowledge and potential nitrogen contribution by Azolla in the paddies. The Scheme was stratified into seven sections and a questionnaire administered to 250 farmers. Data were collected on awareness levels, source, trend of infestation, abundance, fertilizer regimes and management practices. Five farms from each of the sections were also sampled for Azolla coverage and tissue N levels analyzed. Survey data were analyzed using SPSS software and interpreted using descriptive statistics. Biomass sampling data were analyzed using SAS software and means separated using the least significant differences at $\mathrm{P} \leq 0.05$.

The results demonstrated that Azolla has infested nearly all the paddy farms in Mwea. Azolla invasion occurred more than 10 years ago and coverage per unit area was on a decline and stood at $25 \%$. Water shortage and herbicide use were the main reasons associated with this trend. Azolla is conspicuously noticed at transplanting and weeding times. The presence of Azolla in Mwea is enhanced by widespread use of P and K fertilizers and continuous paddy cropping, thus providing a suitable environment for Azolla growth. Azolla was reported to enhance soil fertility, rice yield and yield components. The maximum Azolla biomass coverage was $14.92 \mathrm{t} / \mathrm{ha}$, with a potential nitrogen contribution of $37.6 \mathrm{~kg} \mathrm{~N} / \mathrm{ha}$. Azolla is invasive in Mwea, widespread, beneficial to paddies and with a high potential $\mathrm{N}$ contribution.
\end{abstract}

Keywords: Azolla invasion, Mwea paddies, nitrogen contribution

\section{Introduction}

Azolla fern has a symbiotic association with a cyanobacterium, Anabaena azollae, through which it fixes nitrogen (Carrapico et al., 2002). The nitrogen fixing association is beneficial in rice production system (Armstrong, 1997). The nitrogen fixing ability has made been extensively used as a bio-fertilizer over the years, especially in the Asian continent (Carrapico et al., 1991). The bio-fertilizer potential of Azolla has also been exploited in rice cultivation systems in Italy (Milicia \& Favilli, 1992). In Kenya, Azolla exists in Mwea, Ahero, West Kano, Bunyala, Taveta and TARDA rice Irrigation Schemes. At Ahero Irrigation Scheme, the positive nitrogen potential of the native species Azolla nilotica, was reported in 1982 and 1987 (AIRS, report no. 34 and 57). In Mwea Irrigation Scheme, Azolla filiculoides is invasive (Oyange, 2019). Farmers have christened it "Acquired Immuno-Deficiency Syndrome" due to a fast growth rate and difficulty in management.

Azolla is native to the tropic and temperate areas of the world (Campbell, 2011). However, it has spread worldwide due to human activities (Carapico et al., 2000). The introduced species have in some places eliminated existing ones (Szczęśniak et al., 2009). Findings by McConnachie et al. (2004) have shown that new world species have invaded South, Central, East Africa regions including Kenya. In Ahero-Kenya, Azolla nilotica species was reported in 1981 (AIRS Report, No. 22). However, this species is no longer in existence in Ahero but a new unidentified one is invasive in the Scheme. In Taveta and Tana River Development Authority Irrigation Schemes, a species similar to Azolla nilotica has also been identified (Oyange, 2019). Within Mwea 
Irrigation Scheme paddies, a species closely linked to Azolla filiculoides is in existence. Its source is unknown and farmers have in the past struggled to control it.

Azolla growth and multiplication is affected by environmental conditions; water availability, temperature, $\mathrm{pH}$ and $\mathrm{P}$ content (Lumpkin, 1985). According to Wanjogu et al. (1992), $60 \mathrm{Kg} \mathrm{P}_{2} \mathrm{O}_{5}$ per ha ${ }^{-1}$ plus manure is recommended for paddy rice cultivation in Mwea. Majority of the farmers apply this amount of $\mathrm{P}$ and undertake double cropping which ensures continuous flooding of paddies thus providing a suitable environment for Azolla growth. In addition, farmers in Mwea rotovate flood and fallow their fields 3-4 months prior to paddy transplanting (RiceMAPP, 2012). These practices can enhance Azolla multiplication and spread. The average temperatures of $22{ }^{\circ} \mathrm{C}$ and $\mathrm{pH}$ of 6.5 , which are experienced in Mwea, are also suitable for Azolla growth (Wong $\& \mathrm{Vu}, 1987)$. Quintero et al. (1993) reported that temperature affects relative growth rate, chlorophyll content and nitrogen fixation of plants.

Estimates of the amounts of nitrogen fixed by Azolla in paddy fields are varied but can be up to $1000 \mathrm{~kg} \mathrm{~N} \mathrm{ha}{ }^{-1}$ (IRRI, 1990). Ferentinos et al. (2002) reported that Azolla anabaena complex can fix up to 390 tons $\mathrm{N}$ ha $\mathrm{a}^{-1}$. Apart from nitrogen fixation, Azolla multiplies rapidly and doubles its biomass within 7-10 days (Campbell, 2011). It can therefore attain a biomass coverage of up to $5 \mathrm{~kg} \mathrm{~m}^{-2}$, which is capable of shielding up to $10 \%$ light (Yanni et al., 1994). This is advantageous in controlling some aquatic weeds (Scagel et al., 1966). The fast rate of biomass accumulation, although advantageous, can cause mechanical obstruction, impede water flow and clog irrigation canals (Scagel et al., 1966). With the current global warming and climate change, increase in temperatures and reduced water resources is a reality (Bauckland et al., 2008). This supposes a future risk of reduction in Azolla growth and spread. The study sought to establish the level of awareness, extent of infestation, the management strategies and the potential nitrogen contribution of Azolla in the Mwea paddies during the period of 2016 and 2017 long and short rains.

\section{Materials and Methods}

\subsection{Site Description}

The study was conducted in Mwea Irrigation Scheme, during the year 2016. Mwea Irrigation Scheme is located about $100 \mathrm{~km}$ East of Nairobi, along Nairobi-Meru road at an altitude of 1159 metres above the sea levels, $0^{\circ} 37^{\prime} \mathrm{S}$ and $37^{\circ} 27^{\prime} \mathrm{E}$. The climate is tropical within agro-ecological zones Lower Midland 3 and Lower Midland 4. Rainfall pattern is bimodal with an annual mean of about $930 \mathrm{~mm}$ and an average temperature of $22{ }^{\circ} \mathrm{C}$. The scheme is approximately 8,000 hectares and is subdivided into seven sections namely: Mwea (M), Tebere (T), Thiba (H), Wamumu (W), Karaba (K), Ndekia and Mutithi/Curukia (Figure 1). Irrigation water is sourced from two rivers; Thiba and Nyamindi.

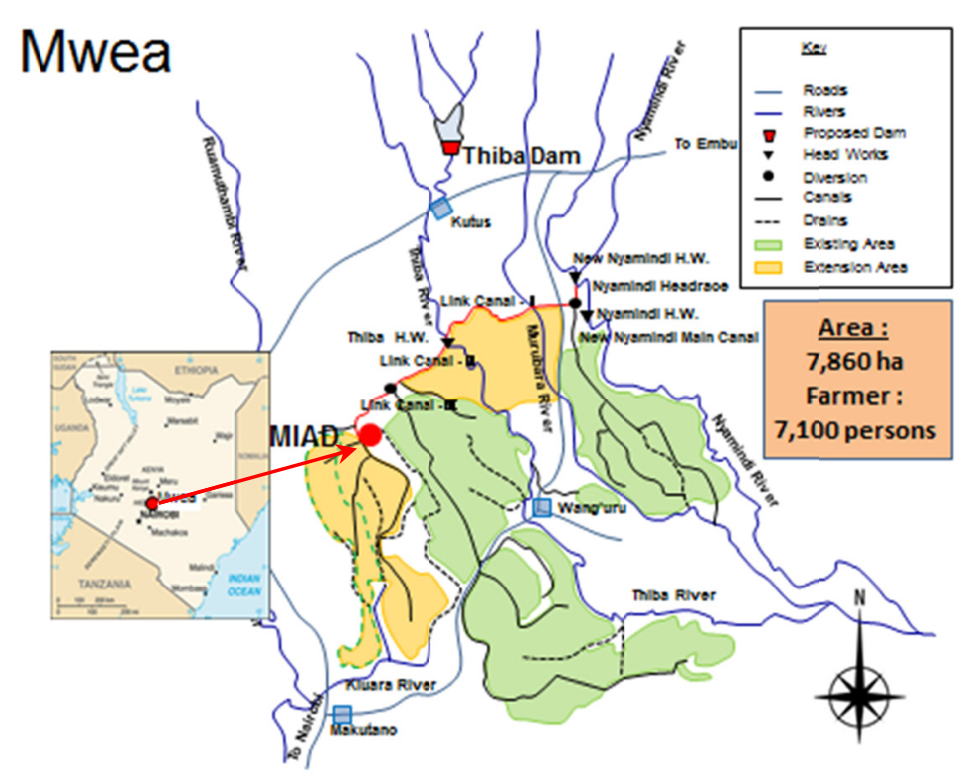

Figure 1. A map showing Mwea Irrigation Scheme in Kenya (Source: NIB) 


\subsection{Experimental Design and Sampling}

The survey was conducted within the seven sections of Mwea Irrigation Scheme namely: Mwea, Tebere, Thiba, Wamumu, Karaba, Ndekia and Mutithi/Curukia, with 6,049 households. The study used stratified sampling design, and 40 farmers each from the seven sections of the scheme were randomly selected from the Irrigation Water Users Association list and questionnaire administered to obtain data on Azolla awareness, infestation trend, sources, management and perception. The questionnaires were pre-tested with 20 farmers in Thiba section of the scheme; to assess in its clarity to the respondents. Stratified sampling technique was used to sample a total of 250 farmers who were interviewed out of the 280 targeted to achieve a minimum of $10 \%$ statistical requirement (Orodho, 2005). Both qualitative and quantitative modes of inquiry were used. Secondary data was collected though literature review while primary data by in-depth interviews with the respondents.

In addition to the survey, a sample of $100 \mathrm{~g}$ fresh Azolla biomass and $500 \mathrm{ml}$ of water were collected from the irrigation canals of each of the seven sections for plant tissue nutrient $(\mathrm{N}, \mathrm{P}$ and $\mathrm{K})$ and irrigation water quality $(\mathrm{N}, \mathrm{P}, \mathrm{K}$, and $\mathrm{pH})$ analysis. Collected fresh biomass was oven dried to a constant weight in the laboratory at 100 ${ }^{\circ} \mathrm{C}$ for 24 hours and dry weight determined (Faichney \& White, 1983). About $5 \mathrm{~g}$ of Azolla dry matter was then used to determine the nitrogen content using Kjeldahl's method (Kjeldahl, 1883), P content by calorimetric method (Barton, 1948) and K content by flame photometry method (Schollenberger \& Simon, 1945). From the irrigation water samples, $\mathrm{N}$ content was analysed using the procedure by Kjeldahl (Kjeldahl, 1883), P content by orthophosphate method (Jackson, 1958), K content by atomic absorption method (Fishman, 1965) and pH by glass electrode method (Jackson, 1958). From each of the seven sections of the scheme, five farms were randomly selected, and Azolla biomass per unit area measured by sampling three (3) $1 \mathrm{~m}^{2}$ unit areas. The potential nitrogen contribution per unit area was then calculated by multiplying the average dry mater weight per unit area $\mathrm{x} \%$ tissue $\mathrm{N}$.

\subsection{Data Analysis}

Survey data was analysed using SPSS version 20 and Chi square test done to determine relationship between variables. Data for tissue nutrient, irrigation water quality and potential nitrogen contribution data were analysed using SAS software and means separated using the least significant difference (LSD) test at $p \leq 0.05$. Regression analysis was conducted to determine the relationship between Azolla tissue nutrient and irrigation water quality.

\section{Results}

\subsection{Azolla Infestation in Mwea Irrigation Scheme Paddies}

Nearly $100 \%$ of the respondents were aware of the presence of Azolla in Mwea Irrigation Scheme. The fern was reported to have infested an average of $97 \%$ of the farms within Mwea Irrigation Scheme. The percentage of farmers whose farms had been infested by Azolla ranged from 94\% (Wamumu) to 100\% (Ndekia) as shown in Table 1. There was no significant relationship $(\mathrm{P}>0.05)$ between awareness and the various sections of the Scheme as shown by the Chi test.

Table 1. Percentage of farmers having seen Azolla in their paddy fields in Mwea Irrigation Scheme

\begin{tabular}{llll}
\hline Section & Yes $\mathbf{( \% )}$ & No $\mathbf{( \% )}$ & Total $\mathbf{( \% )}$ \\
\hline Tebere & 96 & 4 & 100 \\
Thiba & 95 & 5 & 100 \\
Mwea & 97 & 3 & 100 \\
Wamumu & 94 & 6 & 100 \\
Karaba & 97 & 3 & 100 \\
Ndekia & 100 & 0 & 100 \\
Mutithi/Curukia & 100 & 0 & 100 \\
\hline Average & $\mathbf{9 7}$ & $\mathbf{2 . 8}$ & $\mathbf{1 0 0}$ \\
$\mathbf{x}^{\mathbf{2}} \mathbf{( 6 )}=\mathbf{1 . 7 1 , \mathbf { P } = \mathbf { 0 . 9 8 3 }}$ & & & \\
\hline
\end{tabular}

\subsection{Azolla Invasion in Mwea Irrigation Scheme}

Azolla infestation in Mwea Irrigation Scheme was first noticed more than 10 years ago within Thiba, Wamumu, Karaba, Tebere and Mwea sections by 31.7, 25, 25, 17 and 6.7\% of the respondents respectively (Table 2). In 
Ndekia and Mutithi/Curukia, infestation was first noticed within the last 5-10 years. The time of infestation had a significant $(\mathrm{P}=0.022)$ relationship with the various sections of the scheme (Table 2$)$.

Table 2. Time of Azolla invasion in various sections of Mwea Irrigation Scheme (\% respondents)

\begin{tabular}{lllll}
\hline Section & No idea & $<\mathbf{5}$ years ago & $\mathbf{5 - 1 0}$ years ago & $>\mathbf{1 0}$ years ago \\
\hline Tebere & 4.3 & 31.9 & 46.8 & 17.0 \\
Thiba & 0.0 & 31.7 & 36.6 & 31.7 \\
Mwea & 13.3 & 53.3 & 26.7 & 6.7 \\
Wamumu & 12.5 & 25.0 & 37.5 & 25.0 \\
Karaba & 3.1 & 18.8 & 53.1 & 25.0 \\
Ndekia & 0.0 & 75.0 & 25.0 & 0.0 \\
Mutithi/Curukia & 0.0 & 62.5 & 37.5 & 0.0 \\
\hline Average & $\mathbf{4 . 7}$ & $\mathbf{4 2 . 6}$ & $\mathbf{3 7 . 6}$ & $\mathbf{1 5 . 1}$ \\
$\mathbf{x}^{\mathbf{2}}(\mathbf{1 8})=\mathbf{3 2 . 0}, \mathbf{P}=\mathbf{0 . 0 2 2}$ & & & \\
\hline
\end{tabular}

\subsection{Trend of Azolla Infestation in Mwea Irrigation Scheme}

Azolla infestation has been on the decline according to $71 \%$ of the respondents (Tables 3 and 4). The trend of coverage was however reported to be on the increase in Mutithi/Curukia. More than 10 year ago, about $48 \%$ of the farms had more than 50\% Azolla coverage compared with 14\% (5-10 years ago) and 12\% currently. The trend of coverage had significant $(\mathrm{P}<0.05)$ relationship with the period of infestation. It was however not related to the sections $(\mathrm{P}>0.05)$ and the unit coverage $(\mathrm{P}>0.05)$ (Tables 3,4 and 5).

Table 3. Trends of Azolla coverage in Mwea irrigation Scheme (\% of respondents)

\begin{tabular}{llll}
\hline Period & No idea & Increasing & Decreasing \\
\hline$<5$ years ago & 15.0 & 17.5 & 67.5 \\
5-10 years ago & 7.9 & 28.9 & 63.2 \\
$>$ 10 years ago & 2.6 & 14.5 & 82.9 \\
\hline Average & $\mathbf{8 . 5}$ & $\mathbf{2 0 . 3}$ & $\mathbf{7 1 . 2}$ \\
$\mathbf{x}^{2}(\mathbf{6})=\mathbf{5 9 . 7}, \mathbf{P}=\mathbf{0 . 0 0 0}$ & & & \\
\hline
\end{tabular}

Table 4. Trends of Azolla coverage in Mwea Irrigation Scheme (\% respondents)

\begin{tabular}{llll}
\hline Section & No idea & Increasing & Decreasing \\
\hline Tebere & 8.5 & 19.1 & 72.3 \\
Thiba & 7.3 & 9.8 & 82.9 \\
Mwea & 10.0 & 20.0 & 70.0 \\
Wamumu & 9.4 & 31.3 & 59.4 \\
Karaba & 3.1 & 21.9 & 75.0 \\
Ndekia & 0.0 & 0.0 & 100.0 \\
Mutithi/Curukia & 12.5 & 50.0 & 37.5 \\
\hline Average & $\mathbf{7 . 7 \%}$ & $\mathbf{2 0 . 6 \%}$ & $\mathbf{7 1 . 6 \%}$ \\
$\mathbf{x}^{\mathbf{2}} \mathbf{( 1 2 )}=\mathbf{1 3 . 4 ,} \mathbf{P}=\mathbf{0 . 5 4}$ & & & \\
\hline
\end{tabular}

Table 5. Azolla coverage per unit area in Mwea Irrigation Scheme (\% respondents)

\begin{tabular}{lllll}
\hline Period & Nil & $<\mathbf{2 5 \%}$ coverage & $\mathbf{2 5 - 5 0 \%}$ coverage & $>\mathbf{5 0 \%}$ coverage \\
\hline 2016 (currently) & 29.0 & 48.9 & 9.7 & 12.4 \\
$5-10$ years ago & 7.3 & 31.8 & 46.9 & 14.0 \\
$>10$ years ago & 19.4 & 20.9 & 11.6 & 48.1 \\
Average & $\mathbf{1 8 . 6}$ & $\mathbf{3 3 . 9}$ & $\mathbf{2 2 . 7}$ & $\mathbf{2 4 . 8}$ \\
$\mathbf{x}^{\mathbf{2}}(\mathbf{9})=\mathbf{1 1 . 9}, \mathbf{P}=\mathbf{0 . 0 2 2}$ & & & & \\
\hline
\end{tabular}




\subsection{Major Reasons for Declining Levels of Azolla Biomass in Paddy Fields}

The reduction in Azolla levels in the paddies was attributed mainly to increased water shortage and herbicide use. A large percentage (21.9\%) of farmers from Karaba section of the scheme had no idea of the reason for reduced levels of Azolla biomass in the paddy fields. There was no significant $(\mathrm{P}>0.05)$ relationship between the reasons and the various sections of the scheme (Table 6).

Table 6. Reasons for reduction in Azolla biomass coverage in Mwea Irrigation Scheme paddies (\% respondents)

\begin{tabular}{lllllll}
\hline Section & Water shortage & No idea & Soil fertility & Herbicide & Drying after cropping & Others \\
\hline Tebere & 68.1 & 6.4 & 0.0 & 14.9 & 6.4 & 4.3 \\
Thiba & 82.9 & 2.4 & 4.9 & 7.3 & 0.0 & 2.4 \\
Mwea & 76.7 & 3.3 & 0.0 & 16.7 & 0.0 & 3.3 \\
Wamumu & 71.9 & 3.1 & 0.0 & 15.6 & 9.4 & 9.4 \\
Karaba & 75.0 & 21.9 & 3.1 & 0.0 & 0.0 & 0.0 \\
Ndekia & 100.0 & 0.0 & 0.0 & 0.0 & 0.0 & 0.0 \\
MC & 100.0 & 0.0 & 0.0 & 0.0 & 0.0 & 0.0 \\
\hline Average & $\mathbf{8 2 . 1}$ & $\mathbf{5 . 3}$ & $\mathbf{1 . 1}$ & $\mathbf{7 . 8}$ & $\mathbf{2 . 3}$ & $\mathbf{1 . 4}$ \\
$\mathbf{x}^{\mathbf{2}} \mathbf{( 4 2 )}=\mathbf{5 3 . 6 ,} \mathbf{P}=\mathbf{1 . 0 8}$ & & & & & &
\end{tabular}

Note $. \mathrm{MC}=$ Mutithi/Curukia Others $=$ weeding, manual removal.

\subsection{Irrigation Water Availability in Mwea Irrigation Scheme}

Irrigation water availability was reported to be generally poor in Karaba, Ndekia and Mutithi/Curukia (Table 7). However, in Thiba and Tebere sections of the scheme, about $51 \%$ and $47 \%$ of the respondents, respectively, reported that the water situation ranged from good to very good. The water availability had significant $(\mathrm{P}<0.05)$ relationship with the various sections of the scheme (Table 7).

Table 7. Irrigation water availability in various sections of Mwea Irrigation Scheme (\% respondents)

\begin{tabular}{|c|c|c|c|c|}
\hline Section & Poor & Good & Very good & Others \\
\hline Tebere & 8.5 & 36.2 & 10.6 & 44.7 \\
\hline Thiba & 17.1 & 43.9 & 7.3 & 31.7 \\
\hline Mwea & 6.7 & 23.3 & 3.3 & 66.7 \\
\hline Wamumu & 0.0 & 0.0 & 0.0 & 100.0 \\
\hline Karaba & 71.9 & 21.9 & 3.1 & 3.1 \\
\hline Ndekia & 0.5 & 25.0 & 0.0 & 25.0 \\
\hline Mutithi/Curukia & 62.5 & 12.5 & 0.0 & 25.0 \\
\hline Average & 22.2 & 26.3 & 5.2 & 46.4 \\
\hline$x^{2}(18)=118, P=0.000$ & & & & \\
\hline
\end{tabular}

\subsection{Source of Azolla in Mwea Irrigation Scheme paddies}

About $83 \%$ of the respondents reported that irrigation water was the main source of Azolla infestation followed by Quelea quelea $(1.1 \%)$ and Air $(0.7 \%)$ as shown in Table 8 . On average, $13.2 \%$ of the respondents were not aware of the source of Azolla infestation. Ndekia section had the highest percentage of respondents not aware of Azolla infestation (50\%). There was no significant $(\mathrm{P}>0.05)$ relationship between the sources of infestation and the various sections of the scheme (Table 8). 
Table 8. Sources of Azolla infestation in Mwea Irrigation Scheme (\% respondents)

\begin{tabular}{lllllll}
\hline Section & Water & Birds & Air & No idea & Others & Machines \\
\hline Tebere & 83.0 & 0.0 & 0.0 & 11.0 & 2.0 & 0.0 \\
Thiba & 88.0 & 2.0 & 0.0 & 10.0 & 0.0 & 0.0 \\
Mwea & 77.0 & 3.0 & 3.0 & 10.0 & 0.0 & 3.0 \\
Wamumu & 78.0 & 3.0 & 0.0 & 19.0 & 0.0 & 0.0 \\
Karaba & 84.0 & 0.0 & 0.0 & 16.0 & 0.0 & 0.0 \\
Ndekia & 50.0 & 0.0 & 0.0 & 50.0 & 0.0 & 0.0 \\
Mutithi/Curukia & 63.0 & 0.0 & 13.0 & 13.0 & 0.0 & 0.0 \\
Average & 82,5 & 1.1 & 0.7 & 13.2 & 0.3 & 0.4 \\
$\mathbf{x}(\mathbf{3 6})=\mathbf{3 9 . 5 ,} \mathbf{P}=\mathbf{0 . 3 2}$ & & & & & & \\
\hline
\end{tabular}

\subsection{Peak Periods of Azolla Infestation}

Azolla was reported to be most abundant at rice transplanting and weeding stages by $42 \%$ and $49.8 \%$ of the respondents respectively (Table 9). In Ndekia, Karaba and Mwea sections of the scheme, prevalence was reported to be at weeding stage while in Tebere and Thiba, prevalence was at transplanting stage of rice. Equal proportion of respondents in Wamumu section (40.6\%), reported equal prevalence at both transplanting and weeding stages of rice. The relationship between peak times of infestation and the Sections of the scheme was significant $(\mathrm{P}<0.05)$.

Table 9. Peak periods of Azolla infestation in Mwea Irrigation Scheme (\% respondents)

\begin{tabular}{lllll}
\hline Section & Transplanting time & Weeding time & Heading time & No idea \\
\hline Tebere & 72.3 & 19.1 & 2.1 & 6.4 \\
Thiba & 65.9 & 26.8 & 0.0 & 7.3 \\
Mwea & 40.0 & 46.7 & 6.7 & 6.7 \\
Wamumu & 40.6 & 40.6 & 6.3 & 12.5 \\
Karaba & 31.3 & 65.6 & 3.1 & 0.0 \\
Ndekia & 0.0 & 100.0 & 0.0 & 0.0 \\
\hline Average & $\mathbf{4 1 . 7}$ & $\mathbf{4 9 . 8}$ & $\mathbf{3 . 0}$ & $\mathbf{5 . 5}$ \\
$\mathbf{x}^{\mathbf{2}}(\mathbf{1 8})=\mathbf{3 9 . 2} \mathbf{P}=\mathbf{0 . 0 3}$ & & & & \\
\hline
\end{tabular}

\subsection{Herbicide Use in Rice Production}

The types of herbicides used by farmers in Mwea paddies and the frequency of application are shown in Tables 1.10 and 1.11. Use of herbicides for weed control in Mwea Irrigation Scheme was noted to be prevalent with about $95 \%$ of the respondents using herbicides for weed control. Out of these, about $54 \%$ used glyphosate based pre-plant herbicides while $31 \%$ applied 2,4-D based post-emergent selective herbicides. Only $13 \%$ were reported to be using both pre-plant and post-emergent herbicides. Ndekia and Mwea sections of the scheme reported the highest use of pre-plant herbicides at $75 \%$ and $63 \%$ respectively. The use of post emergent herbicides was highest in Wamumu section (41\%).

Out of the $95 \%$ respondents who confirmed using herbicides, majority (71\%) used it but not always. Comparatively, Wamumu section of the scheme reported the highest number of farmers (43\%) who always used herbicides. In this section of the scheme, a comparatively higher proportion of farmers $(40.6 \%)$ used post-emergent herbicides compared with $13.3 \%$ in Mwea section. The type of herbicides and the frequency of use had no significant $(\mathrm{P}>0.05)$ relationship with the sections of the scheme (Tables 10 and 11). 
Table 10. Types of herbicide used by farmers in Mwea Irrigation Scheme (\% respondents)

\begin{tabular}{lllll}
\hline Section & Pre-plant herbicide & Post-emergent herbicide & Pre-plant+Post-emergent & No idea \\
\hline Tebere & 44.7 & 36.2 & 12.8 & 6.4 \\
Thiba & 58.5 & 26.8 & 12.2 & 2.4 \\
Mwea & 63.3 & 13.3 & 10.0 & 13.3 \\
Wamumu & 50.0 & 40.6 & 3.1 & 6.3 \\
Karaba & 50.0 & 37.5 & 6.3 & 6.3 \\
Ndekia & 75.0 & 25.0 & 0.0 & 0.0 \\
Mutithi/Curukia & 37.5 & 37.5 & 25.0 & 0.0 \\
Average & $\mathbf{5 4 . 1}$ & $\mathbf{3 1 . 0}$ & $\mathbf{9 . 9}$ & $\mathbf{5 . 0}$ \\
$\left.\mathbf{x}^{\mathbf{2}} \mathbf{1 2}\right)=\mathbf{1 2 . 5 ,} \mathbf{P}=\mathbf{0 . 4 1}$ & & & \\
\hline
\end{tabular}

Table 11. Frequency of herbicide use by farmers in Mwea Irrigation Scheme (\% respondents)

\begin{tabular}{llll}
\hline Section & Sometimes & Always & Never \\
\hline Tebere & 68.1 & 27.7 & 4.3 \\
Thiba & 73.2 & 24.4 & 2.4 \\
Mwea & 78.6 & 14.3 & 7.1 \\
Wamumu & 53.1 & 43.8 & 3.1 \\
Karaba & 80.6 & 12.9 & 6.5 \\
Ndekia & 100.0 & 0.0 & 0.0 \\
Mutithi/Curukia & 75.0 & 25.0 & 0.0 \\
\hline Average & $\mathbf{7 5 . 5}$ & $\mathbf{2 1 . 2}$ & $\mathbf{3 . 3}$ \\
$\mathbf{x}^{\mathbf{2}} \mathbf{( 1 2 )}=\mathbf{3 9 . 2 0}, \mathbf{P}=\mathbf{0 . 3 4}$ & & \\
\hline
\end{tabular}

\subsection{Fertilizer Regimes}

In Mwea, farmers use both manure and inorganic fertilizers to supply nutrients required by rice plant. About $46 \%$ of the respondents reported using triple superphosphate+ muriate of potash (as basal) followed by sulphate of ammonia (as a top-dress). This was followed by $22.7 \%$ of the respondents using triple super phosphate + Muriate of potash + manure (as basal), followed by sulphate of ammonia (as top-dress). Relatively a high percentage of farmers $(21.8 \%)$ was reported to be using other recommended practices of basal fertilizer application and a top-dress. There was a significant $(\mathrm{P}<0.05)$ relationship between fertilizer regimes and various sections of the scheme (Table 12).

Table 12. Types of fertilizers used in Mwea Irrigation Scheme (\% respondents)

\begin{tabular}{|c|c|c|c|c|c|c|}
\hline Section & TSP/DAP+MOP+SA & TSP/DAP+MOPSA+Manure & TSP/DAP+SA & 17/23+SA+Manure & 17/23+SA & Others \\
\hline Tebere & 6.4 & 4.3 & 0.0 & 2.1 & 8.5 & 78.8 \\
\hline Thiba & 61.0 & 24.4 & 7.3 & 0.0 & 0.0 & 7.3 \\
\hline Mwea & 50.0 & 33.3 & 3.3 & 3.3 & 0.0 & 10.0 \\
\hline Wamumu & 34.4 & 43.8 & 18.8 & 0.0 & 0.0 & 3.1 \\
\hline Karaba & 68.8 & 28.1 & 0.0 & 0.0 & 0.0 & 3.1 \\
\hline Ndekia & 25.0 & 25.0 & 25.0 & 0.0 & 0.0 & 25.0 \\
\hline Mutithi/Curukia & 75.0 & 0.0 & 0.0 & 0.0 & 0.0 & 25.0 \\
\hline Average & 42.8 & 23.7 & 7.8 & 0.8 & 1.2 & 21.8 \\
\hline
\end{tabular}

$\mathrm{x}^{2}(\mathbf{1 0 8})=\mathbf{2 3 4 . 9}, \mathrm{P}=\mathbf{0 . 0 0}$

Note. Application rates for TSP, DAP, MOP, 17:17:10, 23:23:0 $=2.5$ bags ha $^{-1} ; \mathrm{SA}=5$ bags ha $^{-1}$; Manure $=5$ tons $\mathrm{ha}^{-1}$.

\subsection{Cropping Systems and Rice Yields}

There are four cropping systems in Mwea Irrigation Scheme namely: rice-ratoon, rice-ratoon-rice, rice-rice and rice fallow (Table 13). It was estimated that rice-rice system (double cropping) and rice once (single cropping) 
yielded 28.5 and 23 bags per acre respectively. The cropping system had no significant $(\mathrm{P}>0.05)$ relationship with the yields (Table 13).

Table 13. Rice yields in different rice cropping systems in Mwea Irrigation Scheme (\% respondents)

\begin{tabular}{llll}
\hline & $\mathbf{2 0 - 2 3}$ bags/acre & $\mathbf{2 4 - 2 6}$ bags/acre & $\mathbf{2 7 - 3 0}$ bags/acre \\
\hline Rice-ratoon & 14.5 & 26.7 & 58.8 \\
Rice-ratoon-Rice & 7.1 & 42.9 & 50.0 \\
Rice-fallow & 0.0 & 33.3 & 66.7 \\
Rice-Rice & 0.0 & 0.0 & 100.0 \\
\hline $\mathbf{x}^{\mathbf{2}}(\mathbf{8})=\mathbf{6 . 7}, \mathbf{P}=\mathbf{0 . 5 7}$ & & \\
\hline
\end{tabular}

Note. There were no yields of less than 20 bags or more than 30 bags per acre.

\subsection{Farm Productivity and Effect of Azolla on Soil Fertility and Yield}

The survey showed that majority (43\%) of the farmers obtained an average of 28.5 bags of paddy per acre, $30 \%$ got 25 bags per acre while the rest harvested an average of 21 bags of paddy per acre (Table 14). A high proportion of the respondents from Thiba (70.7\%) followed by Karaba (60\%) and Tebere $(55.6 \%)$, obtained an average of 28 bags of paddy per acre compared to Ndekia which had 22 bags of paddy per acre.

Majority of the respondents (77\%) reported that Azolla was beneficial, increased soil fertility and consequently rice crop yields (Tables 15 and 16 ). However, $12.5 \%$ reported that it reduced yields while $2.5 \%$ had no idea. Thiba section of the scheme had $90.2 \%$ of the respondents who were knowledgeable about the benefits of Azolla, Tebere $83 \%$ and Mutithi/Curukia (out-growers section) at $62 \%$. About $13 \%$ of the respondents indicated that Azolla reduced crop yields. The level of education affected knowledge of the beneficial effects of Azolla on yield. About $77 \%$ of those with college education reported that Azolla caused an increased effect on yield compared to $70 \%$ and $48 \%$, with secondary and primary education respectively. The relationship between paddy rice yields and the various sections of the scheme was significant $(\mathrm{P}<0.05)$. However, farmers' perception of the effect of Azolla on soil fertility and paddy yields had no significant $(\mathrm{P}>0.05)$ relationship with the various sections of the scheme. The level of education also had no significant $(\mathrm{P}>0.05)$ relationship with the perception of Azolla on yield (Table 17).

Table 14. Average rice yields in Mwea Irrigation Scheme (\% respondents)

\begin{tabular}{llll}
\hline Section & $\mathbf{2 1} \mathbf{~ b a g s / a c r e}$ & $\mathbf{2 5}$ bags/acre & $\mathbf{2 8 . 5}$ bags/acre \\
\hline Tebere & 6.7 & 37.8 & 55.6 \\
Thiba & 14.6 & 14.6 & 70.7 \\
Mwea & 14.3 & 42.9 & 42.9 \\
Wamumu & 3.1 & 25.0 & 71.9 \\
Karaba & 6.7 & 33.3 & 60.0 \\
Ndekia & 100.0 & 0.0 & 0.0 \\
Mutithi/Curukia & 42.9 & 57.1 & 0.0 \\
\hline Average & $\mathbf{2 6 . 9}$ & $\mathbf{3 0 . 1}$ & $\mathbf{4 3 . 0}$ \\
$\mathbf{x}^{\mathbf{2}}(\mathbf{1 2})=\mathbf{5 3 . 4 ,} \mathbf{P}=\mathbf{0 . 0 0 0}$ & & & \\
\hline
\end{tabular}


Table 15. Farmers perception about effects of Azolla on soil fertility in Mwea Irrigation Scheme (\% respondents)

\begin{tabular}{lllll}
\hline Section & Increases & Reduces & No effect & Don't know \\
\hline Tebere & 72.1 & 7.0 & 4.7 & 16.3 \\
Thiba & 86.5 & 10.8 & 2.7 & 0.0 \\
Mwea & 77.8 & 11.1 & 3.7 & 7.4 \\
Wamumu & 100.0 & 0.0 & 0.0 & 0.0 \\
Karaba & 71.4 & 3.6 & 3.6 & 21.4 \\
Ndekia & 100.0 & 0.0 & 0.0 & 0.0 \\
Mutithi/Curukia & 85.7 & 14.3 & 0.0 & 0.0 \\
\hdashline Average & 84.9 & 6.7 & 2.1 & 6.4 \\
$\mathbf{x}^{\mathbf{2}}(\mathbf{1 8})=\mathbf{2 4 . 0 ,} \mathbf{P}=\mathbf{0 . 1 6}$ & & & & \\
\hline
\end{tabular}

Table 16. Farmer's perception of Azolla as increasing rice yields in Mwea Irrigation Scheme (\% respondents)

\begin{tabular}{llll}
\hline Section & Increases & Reduces & No idea \\
\hline Tebere & 83.0 & 4.3 & 12.8 \\
Thiba & 90.2 & 0.0 & 9.8 \\
Mwea & 80.0 & 3.3 & 16.7 \\
Wamumu & 80.0 & 3.3 & 16.7 \\
Karaba & 75.0 & 0.0 & 25.0 \\
Ndekia & 75.0 & 25.0 & 0.0 \\
Mutithi/Curukia & 62.5 & 12.5 & 25.0 \\
\hline Average & $\mathbf{7 8 . 0}$ & $\mathbf{6 . 9}$ & $\mathbf{1 5 . 1}$ \\
$\mathbf{x}^{\mathbf{2}}(\mathbf{1 8})=\mathbf{2 8 . 0}, \mathbf{P}=\mathbf{0 . 0 6}$ & & & \\
\hline
\end{tabular}

Table 17. Perception of the effect of Azolla on yield in Mwea Irrigation Scheme, based on level of education (\% respondents)

\begin{tabular}{llllll}
\hline Education level & Increases & Reduces & No effect & Don't know & Total \\
\hline Primary education & 48.6 & 17.1 & 22.9 & 11.4 & 100.0 \\
Secondary education & 70.1 & 8.4 & 13.1 & 8.4 & 100.0 \\
College education & 76.5 & 17.6 & 0.0 & 5.9 & 100.0 \\
Others & 50.0 & 25.0 & 25.0 & 0.0 & 100.0 \\
\hline Average & $\mathbf{6 5 . 6}$ & $\mathbf{1 1 . 7}$ & $\mathbf{1 4 . 1}$ & $\mathbf{8 . 6}$ & $\mathbf{1 0 0 . 0}$ \\
$\mathbf{x}^{\mathbf{2}}(\mathbf{9})=\mathbf{1 0 . 9}, \mathbf{P}=\mathbf{0 . 2 9}$ & & & & \\
\hline
\end{tabular}

Note. Others $=$ not educated.

\subsection{Management of Azolla}

The management strategies of Azolla in Mwea paddies at transplanting and weeding, involved water drainage (to cause desiccation and death) and incorporation of Azolla in the soil (Table 18). At transplanting, water drainage was common while at weeding, incorporation in the soil together with weeds was practiced. About $76.1 \%$ of the respondents' drained water at transplanting, $16.6 \%$ drained at weeding, while $41.6 \%$ of the respondents incorporated Azolla in the soils at weeding. At other times, about $28 \%$ of the respondents collected and threw away Azolla from the paddy fields.

Table 18. Management of Azolla in Mwea Irrigation Scheme paddies (\% respondents)

\begin{tabular}{llllll}
\hline & Drain water & Incorporate & Throw away & Do nothing & Use herbicides \\
\hline Transplanting & 76.1 & 9.7 & 0.8 & 2.6 & 10.8 \\
Weeding & 18.5 & 41.6 & 0.8 & 39.8 & 1.3 \\
Other times & 16.6 & 6.6 & 28.2 & 4.87 & 0.0 \\
\hline
\end{tabular}

Note. Others times $=$ Fertilizer application, pest and disease control, bird scaring. 


\subsection{Nitrogen, Phosphorus and Potasium Content of Azolla Accessions}

Nitrogen, phosphorus and potassium contents, on a dry weight basis of Azolla from various sections of Mwea ranged from $2.0 \%$ to $3.4 \%, 0.20-0.40 \%$ and $0.24-1.35 \%$ respectively. Azolla collected from Tebere and MC sections had significantly lower $\mathrm{N}$ content than the rest of the sections. Samples from Mwea, Wamumu and Ndekia sections had significantly the highest $\mathrm{P}$ content compared to samples collected from other sections, while Karaba samples had significantly the least P content. Azolla samples from Ndekia and Wamumu had significantly the highest and the least content of K respectively (Table 19).

Table 19. Tissue N, P and K contents of Azolla from different sections of Mwea Irrigation Scheme in 2016

\begin{tabular}{llll}
\hline Accession & $\mathbf{\%} / \mathbf{N}$ & $\mathbf{\%} / \mathbf{P}$ & $\mathbf{\%} / \mathbf{K}$ \\
\hline Mwea & 2.40 & 0.40 & 0.7 \\
Thiba & 2.60 & 0.26 & 0.83 \\
Wamumu & 2.50 & 0.40 & 0.24 \\
Tebere & 2.00 & 0.29 & 0.67 \\
Karaba & 2.30 & 0.20 & 0.68 \\
Ndekia & 3.40 & 0.40 & 1.35 \\
Mutithi/curukia & 2.00 & 0.36 & 1.06 \\
Mean & $\mathbf{2 . 5}$ & $\mathbf{3 5 5 2 . 0}$ & $\mathbf{0 . 8 0}$ \\
P-value & $<\mathbf{0 . 0 0 0}$ & $\mathbf{0 . 0 0 0 1}$ & $\mathbf{0 . 0 0 0 1}$ \\
LSD (0.05) & $\mathbf{0 . 2}$ & $\mathbf{2 4 8 . 4}$ & $\mathbf{0 . 2 7}$ \\
CV (\%) & $\mathbf{3 . 4}$ & $\mathbf{2 . 9}$ & $\mathbf{1 3 . 6}$ \\
\hline
\end{tabular}

\subsection{Irrigation Water Quality}

The level of N, P, K and pH in the irrigation water averaged $9.6 \mathrm{ppm}, 0.8 \mathrm{ppm}, 4.4 \mathrm{ppm}$, and 6.6 respectively (Table 20). Generally, the highest N, P, K and pH levels were from Tebere, Wamumu, Ndekia and Karaba samples respectively. Mutithi/curukia water samples had significantly the highest $\mathrm{Cl}(12.2 \mathrm{meq} / \mathrm{l})$ and Ec levels $(1.0 \mathrm{ds} / \mathrm{m})$. The $\mathrm{N}, \mathrm{pH}, \mathrm{Cl}$ and Ec levels were within acceptable limits based on FAO standards (Ayers and Westcot, 1985).

Table 20. Irrigation water quality from sections of Mwea Irrigation scheme

\begin{tabular}{lllllll}
\hline Accession & $\mathbf{N}(\mathbf{p p m})$ & $\mathbf{P}(\mathbf{p p m})$ & $\mathbf{K}(\mathbf{p p m})$ & $\mathbf{p H}$ & $\mathbf{C l} \mathbf{~ m e q} / \mathbf{l}$ & $\mathbf{E c 2 5 0} \mathbf{d s} / \mathbf{m}$ \\
\hline Mwea & 9.2 & 0.6 & 4.4 & 6.9 & 7.4 & 0.6 \\
Thiba & 6.7 & 0.4 & 5.2 & 6.5 & 5.9 & 0.7 \\
Wamumu & 11.3 & 1.1 & 4.0 & 6.3 & 7.6 & 6.4 \\
Tebere & 12.2 & 0.7 & 45 & 6.3 & 8.3 & 0.5 \\
Karaba & 11.0 & 1.0 & 3.4 & 7.8 & 9.0 & 0.5 \\
Ndekia & 8.2 & 0.5 & 6.4 & 5.9 & 8.3 & 0.5 \\
Mutithi/curukia & 8.9 & 1.0 & 3.5 & 6.8 & 12.2 & 1.0 \\
Mean & $\mathbf{9 . 6}$ & $\mathbf{0 . 8}$ & $\mathbf{4 . 5}$ & $\mathbf{6 . 6}$ & $\mathbf{8 . 1}$ & $\mathbf{0 . 6}$ \\
P-value & $\mathbf{0 . 0 0 0 3}$ & $\mathbf{0 . 0 0 2}$ & $\mathbf{0 . 8 7}$ & $\mathbf{0 . 1 5}$ & $\mathbf{0 . 0 0 0 0 1}$ & $\mathbf{0 . 2 8}$ \\
LSD (0.05) & $\mathbf{1 . 2}$ & $\mathbf{0 . 2}$ & $\mathbf{N S}$ & $\mathbf{N S}$ & $\mathbf{0 . 6 7}$ & $\mathbf{N S}$ \\
CV (\%) & $\mathbf{5 . 0}$ & $\mathbf{1 0 . 2}$ & $\mathbf{2 1 . 4}$ & $\mathbf{5 . 8}$ & $\mathbf{3 . 4}$ & $\mathbf{1 5 , 4}$ \\
\hline
\end{tabular}

3.16 Linear Regresion Relationship Between Azolla Tissue N, P, K and Irrigation Water N, $P$ and $K$ in Mwea Irrigation Scheme

Linear regression analysis showed a strong positive and significant linear relationship between Azolla tissue $\mathrm{N}$ and irrigation water $\mathrm{N}(\mathrm{r}=0.82)$, a weak negative and non-significant relationship between tissue $\mathrm{P}$ and irrigation water $\mathrm{P}(\mathrm{r}=0.24)$ and a non-significant positive relationship between tissue $\mathrm{K}$ and irrigation water $\mathrm{K}(\mathrm{r}$ $=0.43$ ). 


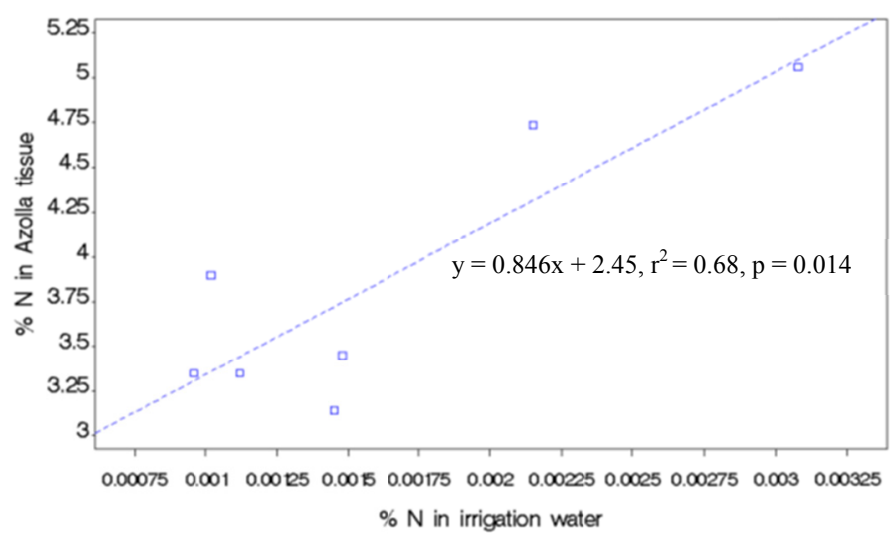

Figure 2. Linear regression relationship between Azolla tissue $\mathrm{N}$ and irrigation water in Mwea Irrigation Scheme

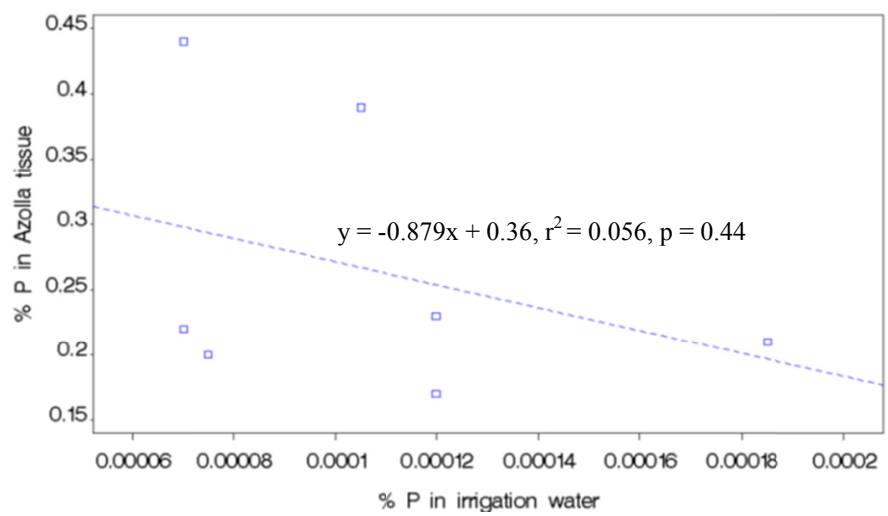

Figure 3. Linear regression relationship between Azolla tissue $\mathrm{P}$ and irrigation water $\mathrm{P}$ in Mwea Irrigation Scheme

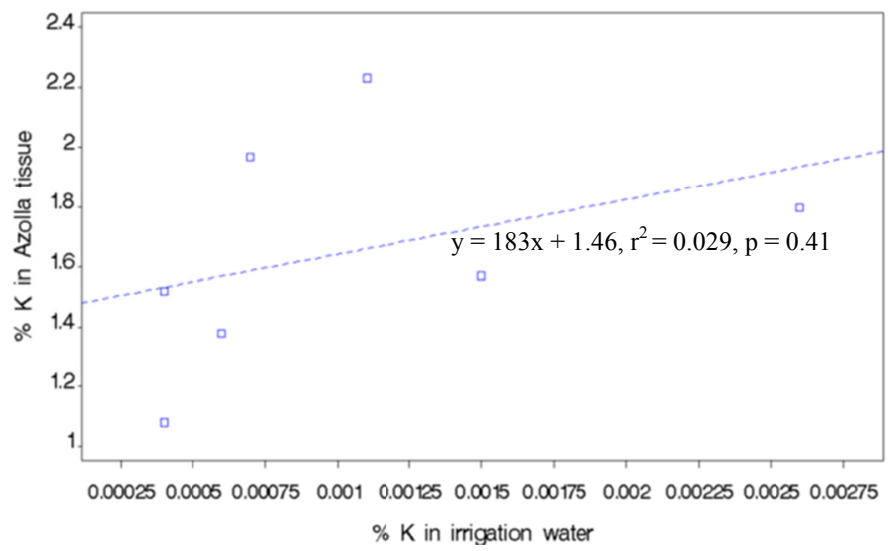

Figure 4. Linear regression relationship between Azolla plant tissue $\mathrm{K}$ and irrigation water $\mathrm{K}$

\subsection{Azolla biomass Levels and Potential N Contribution in Mwea Paddies}

Azolla infestation level and the potential nitrogen contribution in Mwea Paddies are shown in Table 21. Azolla biomass production averaged $8,555.7 \mathrm{~kg} / \mathrm{ha}$ and $286.9 \mathrm{~kg} / \mathrm{ha}$ during the first and second season respectively. Ndekia section had significantly the highest biomass levels of $19,303 \mathrm{~kg} / \mathrm{ha}$ followed by Tebere $(14,725 \mathrm{~kg} / \mathrm{ha})$. The average potential N contribution by Azolla was about $11 \mathrm{~kg} \mathrm{~N} / \mathrm{ha}$ and $0.4 \mathrm{~kg} \mathrm{~N} / \mathrm{ha}$ during the first and second season respectively. Azolla in Ndekia section had the highest potential N $(32.8 .1 \mathrm{Kg} \mathrm{N} / \mathrm{ha})$ contribution followed by Thiba section $(19.1 \mathrm{Kg} \mathrm{N} / \mathrm{ha}$ ). The second season was occasioned by lack of irrigation water due to low rainfall on the Thiba and Nyamindi river sources in Mount Kenya region. 
Table 21. Azolla infestation levels and potential N contribution in paddies at Mwea Irrigation Scheme

\begin{tabular}{lll}
\hline Section & Azolla coverage $(\mathrm{kg} / \mathrm{ha})$ & Potential N $(\mathrm{kg} / \mathrm{ha})$ \\
\hline Season 1 & & \\
Mwea & 7251.0 & 8.7 \\
Thiba & 14725.0 & 19.1 \\
Tebere & 5344.0 & 5.3 \\
Wamumu & 9125.0 & 11.4 \\
Karaba & 2576.0 & 3.0 \\
Ndekia & 19303.0 & 32.8 \\
Mutithi/curukia & 3666.0 & 3.7 \\
\hline Mean & $\mathbf{8 8 5 5 . 7}$ & $\mathbf{1 1 . 1}$ \\
P-value & $<\mathbf{0 . 0 0 0 1}$ & $<\mathbf{0 . 0 0 0 1}$ \\
LSD (0.05) & $\mathbf{4 4 4 5 . 2}$ & $\mathbf{6 . 8}$ \\
CV $(\%)$ & $\mathbf{4 2 . 8}$ & $\mathbf{4 7 . 8}$ \\
\hline Season 2 & & \\
Mwea & 483.0 & 0.6 \\
Thiba & 920.7 & 1.2 \\
Tebere & 230.7 & 0.2 \\
Wamumu & 271.3 & 0.3 \\
Karaba & 6.7 & 0.0 \\
Ndekia & 83.3 & 0.1 \\
Mutithi/curukia & 0.0 & 0.0 \\
\hline Mean & $\mathbf{2 8 6 . 9}$ & $\mathbf{0 . 4}$ \\
P-value & $\mathbf{0 . 0 8 1}$ & $\mathbf{0 . 0 4 9}$ \\
LSD (0.05) & $\mathbf{6 4 6 . 0}$ & $\mathbf{0 . 8}$ \\
CV (\%) & $\mathbf{1 7 2 . 5}$ & \\
\hline & & \\
\hline
\end{tabular}

\section{Discussion}

Results of the survey indicated that Mwea Irrigation Scheme is infested with Azolla fern and on average, 97\% of the farmers were aware of it. Presence of native Azolla species had been reported in Ahero (AIRS Report, No. 42) while Henderson (2002) and McConnachie et al. (2004) reported the invasion of East Africa region by new world species. Majority of the participants had seen Azolla in their farms at Mwea in Irrigation Scheme. Citing of Azolla infestation was first reported in Mwea, Thiba and Tebere sections of the Scheme. These sections are located on the upper parts of the scheme with reliable irrigation water. Infestation of Azolla in Ndekia and Mutithi curukia later during the period is due to the fact that these are out-growers sections, which were brought into rice production after 1998 (Washington-Ottombere \& Evans, 2019). This also explains the significant relationship between the sections and irrigation water supply.

Prevalence of Azolla was reported at weeding and transplanting times. This may be attributed to the predominant farmers' practice of land rotovation, followed by a two-month fallow flooding of paddies. Rice-MAPP (2012) reported this practice in a baseline survey. Flooded paddies are known to provide a good environment for growth of Azolla (Bochi \& Maglioglio, 2010).

Azolla biomass level per unit area was reported to be on a decline. More than 10 years ago, coverage was more than $50 \%$ in an acre and in 2016, it was less than $25 \%$ in an acre. The decline in Azolla biomass levels per unit area over the years can partly be attributed to inadequate irrigation water availability and frequent herbicide use. Nearly $80 \%$ of the respondents reported poor water availability especially in Karaba and Mutithi/Curukia. Karaba is located on the tail part of the scheme, thus being the last section to be supplied with irrigation water. Mutithi/Curukia on the other hand, is an out-growers' section that lacks irrigation infrastructure and normally relies on drainage canals for its supply. Water inadequacy is hence experienced in these areas. The strain on existing water resources has led to the National Irrigation Board implementing a water rationing program to enable all paddy farmers in Mwea scheme to cultivate rice (JICA, 2014). Azolla is an aquatic fern and lack of water exposes the weed to desiccation and death (Bhuvaneshari \& Kumar, 2015). This therefore explains the significant relationship between the various sections and abundance of Azolla. 
The use of herbicides in Mwea Irrigation Scheme is high. More than $90 \%$ of the respondents reported using herbicides. Out of these, $31 \%$ used post emergent herbicides while $51 \%$ used pre-emergent herbicides. Application of post emergent herbicides is normally done within 14 days after transplanting. This is the time period for weeding, which has been coincidentally, reported to also have abundant Azolla biomass. Elsewhere, use of herbicides has been reported to reduce Azolla population (Roncoroni, 2011; Ivens, 1987). In Wamumu section of the scheme, the relatively high usage of herbicides compared to other sections, may partly be a contributory factor to the comparatively low Azolla coverage reported in this section. Comparatively, there were high levels of Azolla infestation in Ndekia, Thiba and Tebere sections of the scheme. This can be associated with the location of the respective sections within proximity to reliable water supply, which enables farmers to practice predominantly rice-rice and rice-ratoon-rice cropping systems. These systems ensure continuous flooding of fields and enhanced Azolla growth. Sadeghi et al. (2013) reported that water availability for Azolla growth is very important. Continuous cropping is also associated with more frequent P-fertilizer application, which is important for Azolla growth. Field analysis showed P levels of about $10.0 \mathrm{ppm}$ which is equivalent to about $23 \mathrm{~kg} \mathrm{P}_{2} \mathrm{O}_{5}$ per ha (Oyange, 2019).

The common management strategies for Azolla by most farmers (75\%) included water drainage at transplanting and incorporation of Azolla into the soil at weeding, to facilitate transplanting and effective weed control respectively. Although the strategy was applied, Azolla continues to infest other parts of Mwea. Use of herbicides for Azolla control has been recommended, but with utmost care (Cilliers et al., 2003). Biological control using weevils (Stenopelmus rufinasus) has been reported to be effective in South Africa (Hill \& Cilliers, 1999). However, Hussner (2010) reported that Azolla lacks proper and effective control strategies.

The general perception of farmers about Azolla was positive. More than $70 \%$ of farmers concurred that Azolla increases soil fertility, tiller numbers and paddy yields. This is in concurrence with reported findings by Ferentinos et al. (2002) that Azolla improves soil quality through soil nitrogen supply. During the survey period, Azolla tissue N\% on a dry weight basis was found to be between 2.4 and 3.4\%. The amounts are closer to the reported range of $4-5 \%$ by Watanabe and Berja (1983). There was a significant positive relationship between Azolla tissue $\mathrm{N}$ and irrigation water N. This suggests that flood water $\mathrm{N}$ increases Azolla tissue N. It is in conformity with reported findings of Sah et al. (1989) that increase of $\mathrm{N}$ in growth media increased Azolla tissue $\mathrm{N}$.

The maximum potential nitrogen contribution was $32.8 \mathrm{~kg} \mathrm{~N} / \mathrm{ha}$ which is about $45 \%$ of the recommended paddy rice $\mathrm{N}$ requirement in Mwea. In the second season, there were no significant differences partly due to long and prolonged drought, which made paddies to dry and caused death of existing Azolla biomass. The potential N contribution of $45 \%$ of the crop requirement therefore implies that Azolla is beneficial to rice crop production. Farmers in Mwea can therefore benefit from reduced cost of production by exploiting integrated Azolla use in paddy rice production system.

\section{Conclusion}

Azolla fern has infested Mwea Irrigation Scheme and it is well known to farmers. Its level of infestation is high although per unit area occupation is on a declining trend due to drought. Farmers in Mwea have appreciated the positive effect of Azolla on paddy rice production although they lack a good management strategy for it. In Mwea Irrigation Scheme, Azolla infestation has positively complemented the soil nutrient status thus reducing inorganic fertilizer requirements.

\section{References}

Armstrong, W. P. (1979). A marriage between a fern and Cyanobacteria. Environmental Southwest, 50, 20-24.

Barton, L. J. (1948). Photometric method of phosphate rock analysis. Analytical Chemistry, 20, 1068-1070. https://doi.org/10.1021/ac60023a024

Bauckland, P., Janettos, A., \& Schimel, D. (2008). The effects of climate change on Agriculture, Land resources, water resources and Biodiversity in the United States, US climate change Science Program. Synthesis and Assessment Product, 4(3).

Bhuvaneshwari, K., \& Singh, K. (2015). Response of nitrogen-fixing water fern Azolla bio-fertilization to rice crop. Biotechnology, 5(4), 523-529. https//doi.org/10.1007/s13205-014-0251-8

Campbell, R. (2011). Azolla growth in farm dams. Agriculture Victoria. Retrieved from http://agriculture.vic.gov. au/agriculture/farm 
Carrapico, F. (2002). Azolla-Anabaena-Bacteria system as a natural microorganism. Proceedings of SPIE 4491, Astrobology Conference IV (pp. 261-265). https://doi.org/10.1117/12.454763

Carrapiço, F., Teixeira, G., \& Diniz, M. (2000). Azolla as a bio-fertiliser in Africa: A challenge for the future. Revista de Ciências Agrárias, 23(3-4), 120-138.

Cilliers, C. J., Hill, M. P., Ogwang, J. A., \& Obinna, A. (2003). Aquatic weeds in Africa and control. Biological Control in IPM Systems in Africa (pp. 161-178). CAB International Wallingford, UK. https://doi.org/ 10.1079/9780851996394.0161

Faichney, G. J., \& White, G. A. (1983). Methods for the analysis of feeds eaten by ruminants (p. 36). Division of Animal Production, Ian Clunies Ross Animal Research Laboratory, Commonwealth Scientific and Industrial Research Organization. Retrieved from https://trove.nla.gov.au/work/21665252

Ferentinos, L., Smith, J., \& Valenzuela, H. (2002). Sustainable agriculture, green manure crops. Retrieved from https://scholarspace.manoa.hawaii.edu/bitstream/10125/12732/SA-GM-2.pdf

Fishman, M. J. (1965). The use of atomic absorption for analysis of natural waters. Atomic Absorption Newsletter, $5,102-106$.

Henderson, L. (2002). Problem plants in Ngorongoro conservation area. Final report to the NCAA in Southern Africa. Biological Control, 29, 326-331.

Hill, M. J., \& Cilliers, C. (1999). Azolla filiculoides Lamarck (Pteridophyta: Azollaceae), its status in South Africa and control. Hydrobiologia, 415, 203-206. https://doi.org/10.1023/A:1003869230591

Hussner, A. (2010). Invasive alien species fact sheet-Azolla filiculoides. NOBANIS. Retrieved from http://www.nobanis.org

International Rice Research Institute. (1990). Low-External Input Rice Production (LIRP) Technology Information Kit (p. 292).

Ivens, G. W. (1987). East African weeds and their control (2nd ed., p. 46).

Jackson, M. L. (1958). Soil chemical analysis (p. 498). Prentice-Hall, Englewood Cliffs, NJ. https://doi.org/ 10.1002/jpln.19590850311

Kjeldahl, J. (1883). A new method for the determination of nitrogen in organic bodies. Analytical Chemistry, 22, 366.

Lumpkin, T. A. (1985). Proceedings of the workshop on Azolla use (pp. 89-90). Fuzhou, Fujian, China.

McConnachie, A. J., Hill, M. P., \& Byrne, M. J. (2004). Field assessment of a frond-feeding weevil, a successful biological control agent of red water fern, Azolla filiculoides, in southern Africa. Biological Control, 9(3), 326-331. https://doi.org/10.1016/j.biocontrol.2003.08.010

Milicia, F., \& Favilli, F. (1992). Azolla symbiotic system's application as bio fertilizer for green garden crops. Symbiosis, 14, 495-500.

Oyange, W. A. (2019). Diversity and effects of Azolla on Paddy rice production in Kenya (Ph.D Thesis).

Quintero, L. R., Espinosa, V. D., \& Ferrera, C. R. (1993). Photoperiod and pH effects on Azolla-Anabaena symbiotic system. International Information System for the Agricultural Science and Technology, 2(11), 193-198.

RiceMAPP (Rice Based Market Oriented Agriculture Promotion Project). (2012). Baseline survey in Mwea Irrigation Scheme (pp. 9-21).

Sadeghi, R., Zarkami, R., Sabetraftar, K., \& Van Damme, P. (2013). A review of some ecological factors affecting the growth of Azolla species. Caspian Journal of Environmental Science, 11(1), 65-76.

Sah, R. N., Goyal, S. S., \& Rains, D. W. (1989). Interactive effects of exogenous combined nitrogen and phosphorus on growth and nitrogen fixation by Azolla. Plant and Soils, 117, 1-8. https://doi.org/ 10.1007/BF02206251

Scagel, F. R., Bandoni, R. F., Rouse, G. E., Schofied, W. B., Stein, J. R., \& Taylor, F. M. C. (1966). An evolutionary survey of the plant Kingdom. Words Word Publication Company, California. 


\section{Copyrights}

Copyright for this article is retained by the author(s), with first publication rights granted to the journal.

This is an open-access article distributed under the terms and conditions of the Creative Commons Attribution license (http://creativecommons.org/licenses/by/4.0/). 